\title{
GERMINATION AND GERM TUBE GROWTH OF THE ARBUSCULAR MYCORRHIZAL FUNGI GIGASPORA ALBIDA IN DIFFERENT SUBSTRATES
}

\author{
Leonor C. Maia*; Adriana M. Yano-Melo \\ Departamento de Micologia, Centro de Ciências Biológicas, Universidade Federal de Pernambuco, Recife, PE, Brasil.
}

Submitted: February 02, 2001; Returned to authors for corrections: April 27, 2001; Approved: November 21, 2001

\begin{abstract}
The role of the substrate on germination of Gigaspora albida Schenck \& Smith was investigated. Spores were desinfested with $0.5 \%$ sodium hypochlorite $(20 \mathrm{~min}$.) and placed on Petri dishes over a Millipore filter, with one of the following media: a- $1 \%$ water-agar; b- water-agar + aqueous extract of roots of Panicum miliaceum L.; c- salt medium of Murashige \& Skoog (MS) or sterilized sand; and incubated in the dark at room temperature $\left(28^{\circ} \mathrm{C} \pm 2\right)$. The experimental design was at random with four treatments and four replicates. Germination was evaluated every 7 days until the $28^{\text {th }}$ day. The water-agar medium was the most feasible for spore germination at the $7^{\text {th }}$ day, followed by the MS medium at the $14^{\text {th }}$ day. Conversely, the sand and the root extract medium did not allow high germination. Spores maintained in water-agar also presented longer germ tubes than spores in the other treatments. Auxiliary cells were observed at the beginning of formation of hyphal branching in all treatments, however they were more numerous in the water-agar medium.
\end{abstract}

Key words: water-agar, MS medium, root extract, Glomales, Panicum miliaceum.

\section{INTRODUCTION}

Arbuscular mycorrhizal fungi (AMF) are associated with plant roots and enhance host growth through increased nutrient uptake. The life cycle of these fungi is initiated by germination of spores which, isolated or in sporocarps, are formed in the soil or sometimes inside the roots (36).

Spores are the most important propagules for most AMF and the impact these organisms produce on their hosts will depend on the ability for fast spore germination and colonization (38).

Spore germination may be affected by many factors, such as: the need for a dormancy period (32), root exudates and/or volatiles; soil moisture, temperature, $\mathrm{pH}$, light and $\mathrm{CO}_{2}(3,10$, $13,35)$; flavonoids $(3,12)$; as well as by presence of bacteria (1), but is independent of the presence of a susceptible host. When Daniels and Graham (6) supplied a $0.75 \%$ water-agar medium with a soil extract $(200 \mathrm{~g}$ soil/L), they observed an increase in the germination rate of Glomus mosseae (Nicol. \& Gerd.) Gerd. $\&$ Trappe spores and mentioned that this resulted from the nutrients extracted from soil. Paula et al. (28) observed that the rates of germination and mycelial growth of $\mathrm{AMF}$ increased $90 \%$ and $200 \%$, respectively, when the water-agar medium was supplemented with plant cells. The greatest increase was observed with the addition of cells of Pueraria phaseoloides Benth. to the medium. Improvement of germination of two Gigaspora species, G. rosea Nicolson \& Schenck and G. decipiens Hall \& Abbott was obtained when spores were placed in different concentrations of cellulase from Trichoderma reese $i$ E. G. Simmons and other fungi (30). Aminoacids may inhibit, activate, or have no effect on mycelial growth of Gigaspora gigantea (Nicol. \& Gerd.) Gerd. \& Trappe pre-germinated in water-agar, depending on the concentration in which they are available in the medium (9). Root membrane permeability under low phosphorus nutrition, lead to net loss of metabolites at levels enough to sustain germination and growth of AMF during pre and post infection (14).

High level of germination in non sterilized soil was reported, although autoclaved, pasteurized or gamma-irradiated soils

\footnotetext{
* Corresponding author. Mailing address: Departamento de Micologia, Centro de Ciências Biológicas, Universidade Federal de Pernambuco, Rua Nelson Chaves, s/n,. Cidade Universitária, 50670-420, Recife, PE, Brasil. Tel.: (+5581) 32718865; Fax (+5581) 32718482; E-mail: leonorcmaia@ @otmail.com
} 
may inhibit the process (7). Germination is also affected by temperature: the ideal temperature for germination of Acaulospora laevis Gerd. \& Trappe was $20^{\circ} \mathrm{C}$, whilst the optimal for hyphal growth was 15 to $25^{\circ} \mathrm{C}$ (39). However, higher germination and hyphal elongation of an isolate of this species in temperatures that varied from 30 to $35^{\circ} \mathrm{C}$ was also observed (24).

Another important factor for germination of AMF is the $\mathrm{pH}$ (15). Spores of A. laevis maintained a few weeks at $6^{\circ} \mathrm{C}$, were exposed to different $\mathrm{pH}$ levels, and germination was higher in low $\mathrm{pH}$. In addition, only $3 \%$ of spores germinated in wateragar, while the rate of germination of spores incubated between filter membrane in soil was higher than $70 \%$.

Many factors such as moisture, aeration, light conditions, microbial activity, and nutrient toxicity affect the abundance, viability, and infectivity of propagules, and therefore directly affect the storage potential of the spores $(5,22,35)$. AMF isolated from temperate environments should be maintained in temperatures from 4 to $10^{\circ} \mathrm{C}$ to break dormancy and enhance germination of spores, whereas those from tropical regions should be stored in environments between 20 to $25^{\circ} \mathrm{C}$. Some species, such as Gigaspora albida Schenck \& Smith may produce multiple germ tubes in vitro (20) which were related to strategies for fungal survival (18).

Considering that information regarding AMF spore germination is still incomplete and that this part of the life cycle is essential for species preservation, the objective of this research was to evaluate the effect of different substrates on germination of spores of G. albida.

\section{MATERIALS AND METHODS}

Spores of G. albida (INVAM 927), grown in pot culture with bahiagrass (Paspalum notatum Flugge) as host plant, were extracted from soil by wet sieving and sucrose centrifugation $(11,17)$. Healthy spores were washed with distilled water, immersed in $0.5 \%$ sodium hypochlorite $(\mathrm{NaOCl})$ for $2 \mathrm{~min}$., and then washed four times in sterilized distilled water (26).

The following substrates were used: A $-1 \%$ water agar (Bacto agar); B. MS salts - Sigma (23), supplemented with 0.2 $\mathrm{ml} / \mathrm{L}$ of claforan (sodic cephotaxima) and $1 \%$ agar; $\mathrm{C}$ - aqueous root extract of Panicum miliaceum L. (50 g of macerated roots plus $100 \mathrm{ml}$ of distilled water) with $1 \%$ agar and $0.2 \mathrm{ml} / \mathrm{L}$ of previously autoclaved claforan; D - sand, sterilized in a microwave oven (8) and placed in covered $46 \times 15 \times 6.7 \mathrm{~cm}$ Nalgene sterilizing trays (Fisher Scientific, Inc., Orlando, Florida). Media A and B were autoclaved at $121^{\circ} \mathrm{C}, 1 \mathrm{~atm}$., for $20 \mathrm{~min}$.

Five spores were transferred to Millipore filters (Gelman Sciences Inc., Ann Arbor, Michigan), and placed on $9 \mathrm{~cm}$ Petri dishes containing media A, B, and C. Spores were also placed between two Millipore filters and transferred to trays with autoclaved sand (medium D). Each Petri dish and box was considered as a replicate, with a total of four replicates per media. Both, Petri dishes and trays with spores were incubated in the dark at room temperature $\left(28^{\circ} \mathrm{C} \pm 2\right)$.

Evaluations were made every 7 days for 28 days. The hypha were stained with drops of $0.05 \%$ aqueous Trypan blue and germination was observed at 40x using a stereomicroscope. Spores which produced germ tubes longer than their diameter were considered to have germinated (2). Germinated spores were expressed as percentage of the total number of evaluated spores. Hyphal length was estimated using the gridline intersect method (25).

The experimental design was a complete factorial of 4 treatments $x 4$ evaluations periods, each with 4 replicates. Data expressed as percentage were arcsin transformed before analyses of variance. The Statistica 5.0 program (37) was used for statistical analysis.

\section{RESULTS AND DISCUSSION}

Germination of this G. albida isolate was affected by substrate. Spores on water agar and MS medium presented the highest germination percentages, which were significantly greater than those in sand and water-agar with root extract (Table 1).

Root exudates of Troyer citrange (Poncirus trifoliata $\mathrm{x}$ Citrus sinensis) and Sudangrass positively influenced germination and germ tube length and branching of Glomus epigaeum Daniels and Trappe (13). Hyphal growth of $G$. margarita Becker \& Hall was stimulated by cell exudates or extracts of Pueraria phaseoloides but was inhibited under high concentration of these substances (27). The results here obtained were different; only $33 \%$ of the spores germinated in the root extract medium. Extract of Asparagus roots did not affect germination of some AMF (7). Although these root extracts are from mycorrhizal susceptible hosts (21), other factors are involved on AMF germination and colonization.

Table 1. Germination of spores and length of germ tubes of Gigaspora albida in: a - water-agar 1\%, b - medium with MS salts, c - water-agar 1\% plus Panicum miliaceum root extract, and $\mathrm{d}$ - sand ( 28 days of incubation).

\begin{tabular}{lcc}
\hline \multicolumn{1}{c}{ Substrate } & Germination (\%) & $\begin{array}{c}\text { Lenght of germ } \\
\text { tube }(\mathbf{m m}) *\end{array}$ \\
\hline Water-agar 1\% & $100 \mathrm{a}$ & $59.62 \mathrm{a}$ \\
MS & $70 \mathrm{a}$ & $43.32 \mathrm{ab}$ \\
Sand & $40 \mathrm{~b}$ & $39.00 \mathrm{~b}$ \\
Root extract & $22.5 \mathrm{~b}$ & $51.56 \mathrm{ab}$ \\
\hline
\end{tabular}

* Mean number of germinated spores. Media followed by the same letter do not differ by the Tukey test at 0.05 . 
Differences in spore germination of AMF due to agar quality were reported: among some types, the Bacto agar allowed higher $(83 \%)$ germination (6). The authors concluded that germination increased according to the increase of agar purity. When using Bacto agar we obtained $88 \%$ of germination, what indicate that it might be favorable to different AMF species.

Germination of G. albida increased over time, depending on the substrate. In water agar, spores reached $100 \%$ of germination at the $7^{\text {th }}$ day. It was reported that the highest germination percentage of Glomus mosseae in $0.75 \%$ water agar occurred on the $26^{\text {th }}$ day (6). In soil and MS medium, the highest level of germination was registered at the $14^{\text {th }}$ day, while spores in root extract had a progressive increase of germination over time but reached only $40 \%$ of germination up to the $28^{\text {th }}$ day of incubation (Fig. 1). In this case, it is possible that the germination had been related to some inhibitory substance present in the root extract, which became inactive with time. Siqueira et al. (34) referred inhibition of germination when organic substances were added to the medium.

More than one germ tube may be produced during germination of spores of G. albida in water agar medium supplied with thiamine (20). However, the same was not observed here. Thus, multiple emission of germ tubes may result from addition of thiamine or other stimulatory substance to the medium. Siqueira et al. (34) mentioned that this substance is part of root exudates. It should also be considered that emission of many germ tubes may be stimulated by substrate conditions, genetic information of the spore, and by physical pressure (35). Emission of more than one germ tube in Gigaspora species may also be due, among other factors, to formation of a germ wall and to the high amount of nuclei near the wall (4).

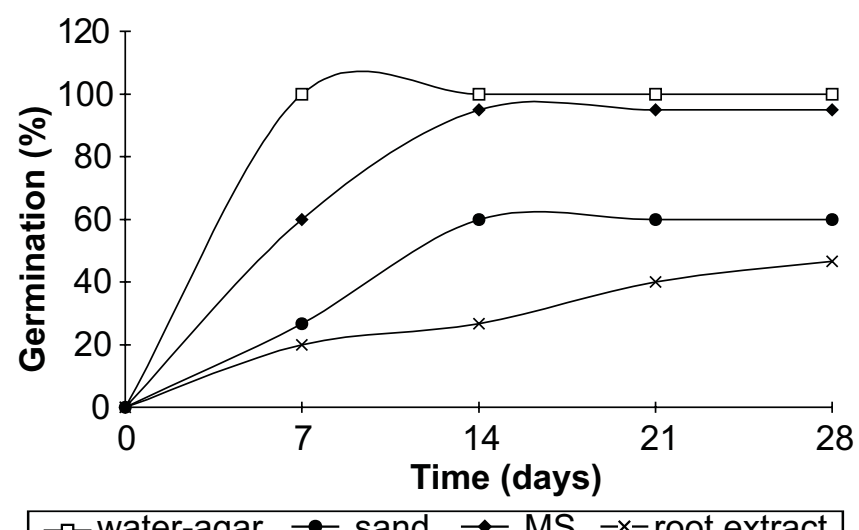

Figure 1. Percentage of germination of spores of Gigaspora albida after 7, 14, 21, and 28 days of incubation in: a - wateragar $1 \%, \mathrm{~b}$ - medium with MS salts, $\mathrm{c}$ - water-agar $1 \%$ plus Panicum miliaceum root extract, and $\mathrm{d}-$ sand.
The higher rate of germination in the MS medium was obtained after 14 days of incubation. Higher germination and micelial growth of G. gigantea, G. margarita, and Scutellospora heterogama was observed when the MS medium was 10x diluted (29). They concluded that high germination was due to decrease in nutrient concentration. Excess of mineral salts in the media may inhibit germination (36). However, this was not observed here, even using the recommended amount of salts in the MS medium.

Addition of a small amount of phosphorus to the agar medium may enhance germination and growth of germ tube (35). The results here obtained are in agreement with this observation, once that the MS medium contained potassium phosphate $\left(170 \mathrm{mg} . \mathrm{L}^{-1}\right)$. Concentration up to $500 \mathrm{mg} . \mathrm{L}^{-1}$ of $\mathrm{P}$ $\left(\mathrm{KH}_{2} \mathrm{PO}_{4}\right)$ did not inhibit germination of some AMF spores (18). Conversely, decrease in germination of spores of Glomus mosseae was observed when $\mathrm{P}$ was added to the medium (31). In a similar way, it was reported that in pasteurized soil, $G$. etunicatum spore germination decreased with increasing P levels up to $60 \mathrm{mg} . \mathrm{L}^{-1}(40)$.

The highest rate of germination in sand was obtained at the $14^{\text {th }}$ day, with almost $65 \%$ of the spores germinated. However, rate of germination higher than $70 \%$ in spores of $A$. laevis placed between filter membranes in soil was observed (15). Disinfestation of the sand through microwave may have impaired germination once that the soil microbiota was eliminated $(7,16)$ and some studies have shown that germination may depend upon a microbial stimulus in non sterile soil (6).

Auxiliary cells were formed in all substrates, mainly after initiation of the branching process in the first hyphae. These structures were more frequently formed in the water agar medium (Fig. 2). Formation of auxiliary cells are not dependent of the growth medium but are supposely related with the intrinsic capacity of the spores (33).

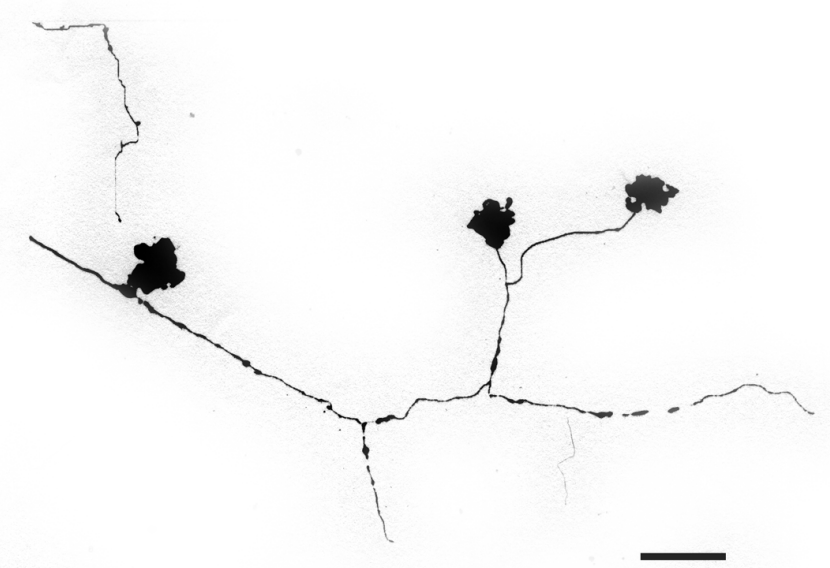

Figure 2. Auxiliary cells of Gigaspora albida, formed after hyphal branching. $\mathrm{Bar}=100 \mu \mathrm{m}$. 
Evaluation of the germ tube length over number of germinated spores showed that these parameters are not related; that is, higher rate of germination does not imply formation of longer germ tubes and the opposite is also true. This was observed in studies (2) with G. albida (GABD 185) and G. gigantea (GGGT 109). After germination, AMF have an energy-saving mechanism which allows long-term infectivity of mycelium even in absence of the host (19) and this would probably depend on spore size (2). Spores maintained in water agar and in the root extract medium presented greater germ tube lengths than those in MS or sand; however, only the treatment in water agar and MS differed significantly (Table 1).

Difficulties in following hyphal growth outside the Millipore filters impaired the evaluation of the effect of time over germ tube length. The lower hyphal length obtained in this work, when compared with other values (3), might be due to the amount of $\mathrm{CO}_{2}$ and flavonols used by the other authors. These factors were not studied in this experiment. On the other hand, the values here obtained were higher than those registered in a previous investigation (2) where germ tubes formed by $G$. albida, in soil, were shorter than $50 \mathrm{~mm}$, after 21 days of incubation. This indicates that several factors determine germ tube growth, even of a same AMF species.

Considering that the effect of the substrate on germination and germ tube growth was confirmed, it might be recommended the use of water agar to improve both processes when working with G. albida.

\section{ACKNOWLEDGEMENTS}

We are grateful to Gladstone Alves da Silva for helping during the experiments, David Douds Jr. for critically reviewing the manuscript, and to the Conselho Nacional de Desenvolvimento Científico e Tecnológico (CNPq) for financial support.

\section{RESUMO}

\section{Germinação e crescimento hifálico do fungo micorrízico arbuscular Gigaspora albida em diferentes substratos}

Foi investigado o papel do substrato sobre a germinação e o crescimento do tubo germinativo de Gigaspora albida Schenck \& Smith. Os esporos foram desinfestados com hipoclorito de sódio a $0,5 \%$ por $20 \mathrm{~min}$. sob agitação constante, lavados com água destilada esterilizada e colocados em membrana de milipore, em placas de Petri com: 1. ágar água $1 \%$, 2. ágar água $1 \%$ + extrato aquoso de raizes de Panicum miliaceum, 3. meio com sais de Murashige \& Skoog (MS) e 4. areia esterilizada. $\mathrm{O}$ material foi incubado no escuro, sob temperatura ambiente $\left(28^{\circ} \mathrm{C} \pm 2\right)$. O delineamento foi inteiramente casualizado, com quatro tratamentos e quatro repetições e a avaliação feita a cada sete dias até completar 28 dias. O meio ágar água $1 \%$ foi o mais propício para germinação $(100 \%)$ após sete dias, seguido pelo meio MS, aos 14 dias. Ao contrário, o solo e o meio com extrato de raiz proporcionaram baixo índice de germinação. Os esporos mantidos em ágar água também apresentaram maior crescimento do tubo germinativo, em relação aos demais tratamentos. Células auxiliares características do gênero foram observadas no início das ramificações hifálicas, em todos os tratamentos, sendo mais numerosas no tratamento em ágar água $1 \%$.

Palavras-chave: ágar-água, extrato de raiz, meio MS, Glomales, Panicum miliaceum.

\section{REFERENCES}

1. Azcón, R. Selective interaction between free-living rhizosphere bacteria and vesicular-arbuscular mycorrhizal fungi. Soil Biol. Biochem. 51(5): 639-644, 1989.

2. Bartolome-Esteban, H.; Schenck, N.C. Spore germination and hyphal growth of arbuscular mycorrhizal fungi in relation to soil aluminum saturation. Mycologia, 86(2): 217-226, 1994.

3. Bécard, G.; Douds, D.D.; Pfeffer, P.E. Extensive in vitro hyphal growth of vesicular- arbuscular mycorrhizal fungi in the presence of $\mathrm{CO}_{2}$ and flavonols. Appl. Environ. Microbiol., 58: 821-825, 1992.

4. Bianciotto, V.; Bonfante, P. Quantification of the nuclear DNA content of two arbuscular mycorrhizal fungi. Mycol. Res., 96(12): 1071-1076, 1998.

5. Clark, R.B. Arbuscular mycorrhizal adaptation, spore germination, root colonization, and host plant growth and mineral acquisition at low pH. Plant Soil, 192: 15-22, 1997.

6. Daniels, B.A.; Graham, S.O. Effects of nutrition and soil extracts on germination of Glomus mosseae spores. Mycologia, 68(1): 108116, 1976.

7. Daniels, B.A.; Trappe, J.M. Factors affecting spore germination of the vesicular-arbuscular mycorrhizal fungus, Glomus epigaeus. Mycologia, 72(3): 457-471, 1980.

8. Ferriss, R.S. Effects of microwave oven treatment on microorganism in soil. Phytopathology, 74(1): 121-126, 1984.

9. Freitas, M.H.; Siqueira, J.O. Crescimento micelial de esporos prégerminados do fungo endomicorrízico Gigaspora gigantea em meio líquido suplementado com compostos orgânicos nitrogenados. Pesq. Agropec. Bras., 29(5): 751-756,1994.

10. Gemma, I.N.; Koske, R.E. Pre-infection interactions between roots and the mycorrhizal fungus Gigaspora gigantea: chemotropism of germ-tubes and root growth response. Trans. Br. Mycol. Soc., 91(1): 123-132, 1988 .

11. Gerdemann, J.W.; Nicolson, T.H. Spores of mycorrhizal Endogone species extracted from soil by wet-sieving and decanting. Trans. Br. Mycol. Soc., 46: 235-244, 1963.

12. Gianinazzi-Pearson, V.; Brazanti, B.; Gianinazzi, S. "In vitro" enhancement of spore germination and early hyphal growth of a vesicular-arbuscular mycorrhizal fungus by host root exudates and plant flavonoids. Symbiosis, 7: 243-255, 1989.

13. Graham, J.H. Effect of Citrus root exudates on germination of chlamydospores of the vesicular-arbuscular mycorrhizal fungus, Glomus epigaeum. Mycologia, 74(5): 831-835, 1982.

14. Graham, J.H.; Leonard, R.T.; Menge, J.A. Membrane-mediated decrease in root exudation responsible for phosphorus inhibition of vesicular-arbuscular mycorrhiza formation. Pl. Physiol., 68: 548552, 1981.

15. Hepper, C.M. Regulation of spore germination of the vesiculararbuscular mycorrhizal fungus Acaulospora laevis by soil $\mathrm{pH}$. Trans. Br. Mycol. Soc., 83(1): 154-156, 1984. 
16. Hetrick, B.A.D.; Wilson, G.W.T. Supression of mycorrhizal fungus spore germination in non-sterile soil: relationship to mycorrhizal growth response in big bluestem. Mycologia, 81(3): 382-390, 1989.

17. Jenkins, W.R. A rapid centrigugal-flotation technique for separating nematodes from soil. Pl. Dis. Report, 48: 692,1964.

18. Koske, R.E. Gigaspora gigantea: observations on spore germination of VA-mycorrhizal fungus. Mycologia, 73: 288-300, 1981.

19. Logi, C.; Sbrana, C.; Giovannetti, M. Cellular events involved in survival of individual arbuscular mycorrhizal symbionts growing in the absence of the host. Appl. Environ. Microbiol., 64(9): 3473 $3479,1998$.

20. Maia, L.C.; Kimbrough, J.W.; Benny, G.L. Ultrastructure of spore germination in Gigaspora albida (Glomales). Mycologia, 86(3): 343-349, 1994.

21. Matsubara, Y.; Harada, T. Effect of arbuscular mycorrhizal fungus infection on growth and mineral nutrient content of Asparagus officinalis seedlings. J. Japanese Soc. Hortic. Sc. 65: 303-309, 1996.

22. Morton, J.B. Storage of fungal propagules, dead or alive. INVAM Newsletter, 4(1), 1994

23. Murashige, T.; Skoog, F. A revised medium for rapid growth and bioassay with tabacco tissue cultures. Physiol. Plantarum, 15: 473497, 1972

24. Nadarajah, P.; Nawawi, A. Effect of temperature on germination and growth of vesicular-arbuscular mycorrhizal fungi. In: Sylvia, D.M.; Hung, L.L.; Graham, S.H. (ed.). Proc. of the $7^{\text {th }}$ NACOM. Gainesville, Florida, 1987, p.214.

25. Newman, G.I. A method of stimating the total lenght of root in a sample. J. Appl. Ecol., 3: 139-145, 1966.

26. Nutila, A.M.; Vestberg, M.; Kauppinen, V. Infection of hairy roots of strawberry (Fragaria x Ananassa Duch.) with arbuscular mycorrhizal fungus. Pl. Cell Reports, 14(8): 505-509, 1995.

27. Paula, M.A.; Siqueira, J.O. Stimulation of hyphal growth of the VA mycorrhizal fungus Gigaspora margarita by suspension cultured Pueraria phaseoloides cells and cell products. New Phytol., 115: 6975, 1990.

28. Paula, M.A.; Siqueira, J.O.; Pinto, J.E.B.P.; Pascal, M. Benefícios da suspensão de células vegetais para fungos micorrízicos vesículo- arbusculares in vitro. 1. Efeito da espécie vegetal e da idade das células. Pesq. Agropec. Bras., 25(8): 1101-1108, 1990a.

29. Paula, M.A.; Siqueira, J.O.; Pinto, J.E.B.P.; Pascal, M. Benefícios da suspensão de células vegetais para fungos micorrízicos vesículoarbusculares in vitro. III. Efeito de diferentes meios de cultivo. Pesq. Agropec. Bras., 25(8): 1117-1124, $1990 \mathrm{~b}$.

30. Persad-Chinnery, S.B.; Chinnery, L.E.; Dales, R.B.G. Enhancement of in vitro spore germination of Gigaspora rosea by a cellulase preparation. Mycol. Res. 96(8): 626-628, 1992.

31. Pons, F. ; Gianinnazzi-Pearson, V. Influence du phosphore, du potassium, de l'azote et du $\mathrm{pH}$ sur le comportement de champignons endomycorrhizogenes a vesicules et arbuscules. Cryptog. Mycol., 5: 87-100, 1984

32. Safir, G.R.; Coley, S.C.; Siqueira, J.O.; Carlson, P.S. Improvement and synchronization of VA mycorrhiza fungal spore germination by short-term cold storage. Soil Biol.Biochem., 22(1): 109-111, 1990

33. Silva, L.R.C.; Siqueira, J.O. Efeitos de carboidratos e ácidos orgânicos sobre o crescimento micelial do fungo endomicorrízico Gigaspora gigantea in vitro. Pesq. Agropec. Bras., 26(11/12): 2007-2014, 1991.

34. Siqueira, J.O.; Hubbel, D.H.; Schenck, N.C. Spore germination and germ tube growth of a vesicular-arbuscular mycorrhizal fungus in vitro. Mycologia, 74(6): 952-959, 1982.

35. Siqueira, J.O.; Sylvia, D.M.; Gibson, J.; Hubbell, D.H. Spores, germination, and germ tubes of vesicular-arbuscular mycorrhizal fungi. Can. J. Microbiol., 31: 965-972, 1985.

36. Smith, S.E.; Read, D.J. Mycorrhizal Symbiosis. 2.ed. Academic Press, London, 1997, 605p.

37. Statistica Ô. Statistica for Windows. Statsoft Inc., Tulsa, USA. 1997.

38. Tommerup, I.C. Spore dormancy in vesicular-arbuscular mycorrhizal fungi. Trans. Br. Mycol. Soc., 81(1): 37-45, 1983a.

39. Tommerup, I.C. Temperature relations of spore germination and hyphal growth of vesicular-arbuscular mycorrhizal fungi in soil. Trans. Br. Mycol. Soc., 81(2): 381-387, 1983b.

40. Wilson, G.W.T.; Hetrick, B.A.D.; Kitt, D.G. Suppression of vesiculararbuscular mycorrhizal fungus spore germination by nonsterile soil. Can. J. Bot. 67: 18-23, 1989. 